\title{
Obituaries
}

Obituaries should be submitted by email to Kate Maynard at k.maynard@nature.com.

All submitted obituaries should be 350 words maximum in length (apart from obituaries for past presidents of the BDA

where the length should be 700-800 words).

Content of the obituary is down to the individual author, and the approval of the family should be given for the obituary prior

to submission to the $B D J$.

\section{ROBERT ALEXANDER DARLING}

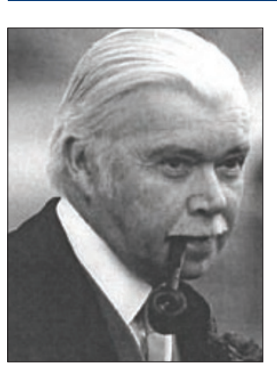

Robert Darling LDS

RCS passed away

on 7 October aged

83. He was born on 10 July 1927 at Dilston Terrace Amble which was the home and dental surgery of his Pa, Norman.

The Crest at Lesbury later became the family home where he lived with his two sisters Margaret and Moira. He was educated at Sedbergh School in Cumberland and wishing to follow his father's career he applied to Newcastle Dental School to be interviewed by the Dean. Robert delighted in telling the story of the shortest interview ever. Instructed to sit down, without uttering a word he was told that one disruptive Darling was enough for any dental school, and he was to go straight home and write to Edinburgh for a prospectus and application form. This he did and two days later, no application form, no prospectus, but a firm offer of a place. Collusion?

The disruptive Darling later became Dean of Bristol Dental School.

In Edinburgh he met his future wife Rae who was reading occupational therapy. Robert took part in Edinburgh life and was appointed to the first Edinburgh Festival Committee, an interest he maintained for many years.

Robert served as an RAF dental officer in the Middle East. After demobilisation he joined his father's practices in Berwick and Alnwick. Being well known in Alnwick Robert and Rae took an active role in the community becoming Presidents of Rotary and Inner Wheel. Robert is still very well remembered in Alnwick where it was his habit at the end of each working day to repair to the Plough Inn where his dog Sandy would be waiting on the doorstep to share in a beer and help with the Times crossword.

Robert was a true country gentleman being more than a passable shot and an expert salmon fisherman on his beat on the Tweed.

It was fitting that Robert and Rae retired to Warkworth where he bought an old pub 'The Red Lion' that had been made into a house.

After Rae died last year Robert bought a scooter on which to go shopping and is well remembered pipe between teeth, helmet on the handlebar and his white hair flowing behind him.

Robert was a true gentleman with a delightful sense of humour and fun. Sorely missed by all who knew him.

P. M.

\section{GEORGE ALEXANDER LAMMIE}

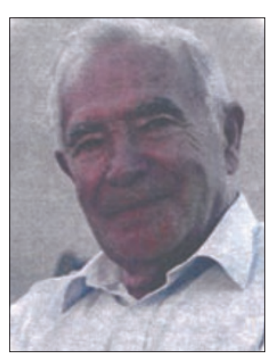

It was a typical March day when we gathered to say goodbye to Sandy Lammie. Educated at George Heriot's School he qualified in dentistry in Edinburgh in 1943.

From then it was a major force in his life. Following graduation he served in the RAF in Africa, and on demob began amassing an enviable list of qualifications which fitted him well for his professional life, both academically and clinically.

Although an enthusiastic clinician his bent was clearly towards academe and he was appointed to posts at Birmingham and Liverpool universities. However, it was possibly his appointment at Northwestern University in Chicago which stimulated the academic curiosity which was the hallmark of the professional life as a general dental practitioner.

His academic background never left him, and he attended and presented at scientific meetings and was a prolific writer until the end of his days. Pleasant memories remain of evenings of intellectual argument (and how he could argue) in his study which boasted a library which could put a small hospital to shame. For Sandy debate was paramount and always supported by factual analysis.

Dentistry was not an exclusive interest. A talented sportsman he played rugby for his old school, reaching a standard where selection for Scotland was a possibility. Although a wartime substitute, these were days when emphasis was given to weight, and although Sandy would freely admit to filling the pockets of his shorts with half crowns he never beat the scales. In later years his love of rugby resulted in trips with friends to Twickenham where he magically obtained tickets, although he maintained that the car park ticket for the pre-match lunch was the most important!

A widely read man with interests in art and literature he was a joy to spend time with. To his widow Elizabeth, daughter Simone, sons Alistair and David and grandchildren we offer our condolences.

Sandy was a man before his time. It was a privilege to know him and dentistry is the poorer for his passing.

The floo'ers o' the forest are a' wede awa'

WREL 